\title{
An investigation into the effects of band gap and doping concentration on $\mathrm{Cu}(\mathrm{In}, \mathrm{Ga}) \mathrm{Se}_{2}$ solar cell efficiency
}

\author{
Md. Asaduzzaman*, Mehedi Hasan and Ali Newaz Bahar
}

\begin{tabular}{l}
\hline${ }^{*}$ Correspondence: \\
asaduzzaman.mbstu@gmail.com \\
Department of Information \\
and Communication \\
Technology, Faculty \\
of Engineering, Mawlana \\
Bhashani Science \\
and Technology University, \\
Tangail 1902, Bangladesh
\end{tabular}

${ }^{*}$ Correspondence: asaduzzaman.mbstu@gmail.com and Communication Technology, Faculty Bhashani Science Tangail 1902, Bangladesh

\begin{abstract}
A simulation study of a $\mathrm{Cu}\left(\mathrm{In}_{1-x} \mathrm{Ga}_{x}\right) \mathrm{Se}_{2}$ (CIGS) thin film solar cell has been carried out with maximum efficiency of $24.27 \%\left(\mathrm{~V}_{\mathrm{oc}}=0.856 \mathrm{~V}, \mathrm{~J}_{\mathrm{sC}}=33.09 \mathrm{~mA} / \mathrm{cm}^{2}\right.$ and $\mathrm{FF}=85.73 \%$ ). This optimized efficiency is obtained by determining the optimum band gap of the absorber and varying the doping concentration of constituent layers. The Ga content denoted by $x=\mathrm{Ga} /(\mathrm{In}+\mathrm{Ga})$ is selected as 0.35 which provides the optimum band gap of absorber layer as $1.21 \mathrm{eV}$. Theoretically, the effects of Ga fraction "X" on CIGS absorber band gap are investigated and to avoid the lattice mismatch effect, the efficiency measurements due to the CIGS band gaps $>1.21 \mathrm{eV}$ have not come to the consideration. A one-dimensional simulator ADEPT/F 2.1 has been used to analyze the fabricated device parameters and hence to calculate open circuit voltage, short circuit current, fill factor and efficiency.
\end{abstract}

Keywords: CIGS thin film, Absorber band gap, Doping concentration, Lattice mismatch, Efficiency

\section{Background}

The CIGS thin film hetero-junction solar cell based on the chalcopyrite p-type absorber layer $\mathrm{Cu}\left(\mathrm{In}_{1-\mathrm{x}} \mathrm{Ga}_{\mathrm{x}}\right) \mathrm{Se}_{2}$ is a promising option in industrial productivity due to its lower manufacturing cost and higher efficiency (Rampino et al. 2015; Powalla and Dimmler 2001; Minemoto et al. 2003). Although the CIGS solar cell is recorded as a highly efficient $(\sim 21.7 \%)$ thin film solar cell (Jackson et al. 2015) either there must still need to enhance efficiency and reduce cost for mass productivity. The inline co-evaporated CIGS absorber (Lindahl et al. 2013) has band gap range from 1.04 (CIS) to $1.67 \mathrm{eV}$ (CGS) depending on $\mathrm{x}$ (from 0 to 1) (Tverjanovich et al. 2006; Gloeckler and Sites 2005; Gabor et al. 1996). The mismatch effect of CIGS layer (Lee et al. 2011) with adjacent CdS buffer layer and Mo back contact is avoided and the absorber band gap is adjusted with its corresponding electron affinity. Furthermore, the doping concentration of different layers is also an important factor to maximize the efficiency and minimize the fabrication cost of any solar cell (Haque and Galib 2013). The influence of the CIGS absorber band gap and the doping concentration of each layer on the performance of the solar cell have been investigated in this study. The radio frequency (RF) sputtered $\mathrm{ZnO}$ (deposition of $\mathrm{Al}$

(c) 2016 The Author(s). This article is distributed under the terms of the Creative Commons Attribution 4.0 International License (http://creativecommons.org/licenses/by/4.0/), which permits unrestricted use, distribution, and reproduction in any medium, provided you give appropriate credit to the original author(s) and the source, provide a link to the Creative Commons license, and indicate if changes were made. 
doped $\mathrm{ZnO}$ and intrinsic $\mathrm{ZnO}$ ) with its wider band gap of $3.3 \mathrm{eV}$ and the chemical bath deposited (CBD) CdS with its direct band gap of $2.42 \mathrm{eV}$ have been used as the window and the buffer layer respectively (Lindahl et al. 2013; Jung et al. 2010). All the efficiency measurements and comparisons are done under a solar spectrum AM1.5G for which the solar irradiance on earth is $0.1 \mathrm{~W} / \mathrm{cm}^{2}$ (Haque et al. 2013). The shadowing factor used in the simulation is of $5 \%$.

\section{Research methodology}

\section{Device modeling}

ADEPT/F 2.1 (Gray et al. 2015), a one dimensional (1D) online research tool is used to analyze the device parameters as well as electrical characteristics of hetero-structured semiconductor devices including single, multi-junction and thin film solar cells. It contributes to the numerical solution of the Poisson's equation and the continuity equation for holes and electrons. The simulator has been used to extract the diagrams such as electric field distribution, current-voltage characteristics, and energy band diagram. From the simulation, it becomes more feasible to calculate the fill factor (FF) and the efficiency. The CIGS model consisting of $\mathrm{n}-\mathrm{ZnO} / \mathrm{n}-\mathrm{CdS} / \mathrm{p}-\mathrm{CIGS}$ layers fabricated on Mo coated soda-lime glass has been proposed for the simulation study. The structural view of $\mathrm{Cu}\left(\mathrm{In}_{1-\mathrm{x}} \mathrm{Ga}_{\mathrm{x}}\right) \mathrm{Se}_{2}$ thin film solar cell used for conducting the simulation is shown schematically in Fig. 1.

\section{Methodological analysis}

The simulation was conducted by formulating the parameters with their corresponding values used in Tables 1 and 2. Afterwards, the highest efficiency for this structure has been calculated by determining the optimum band gap of the absorber layer and

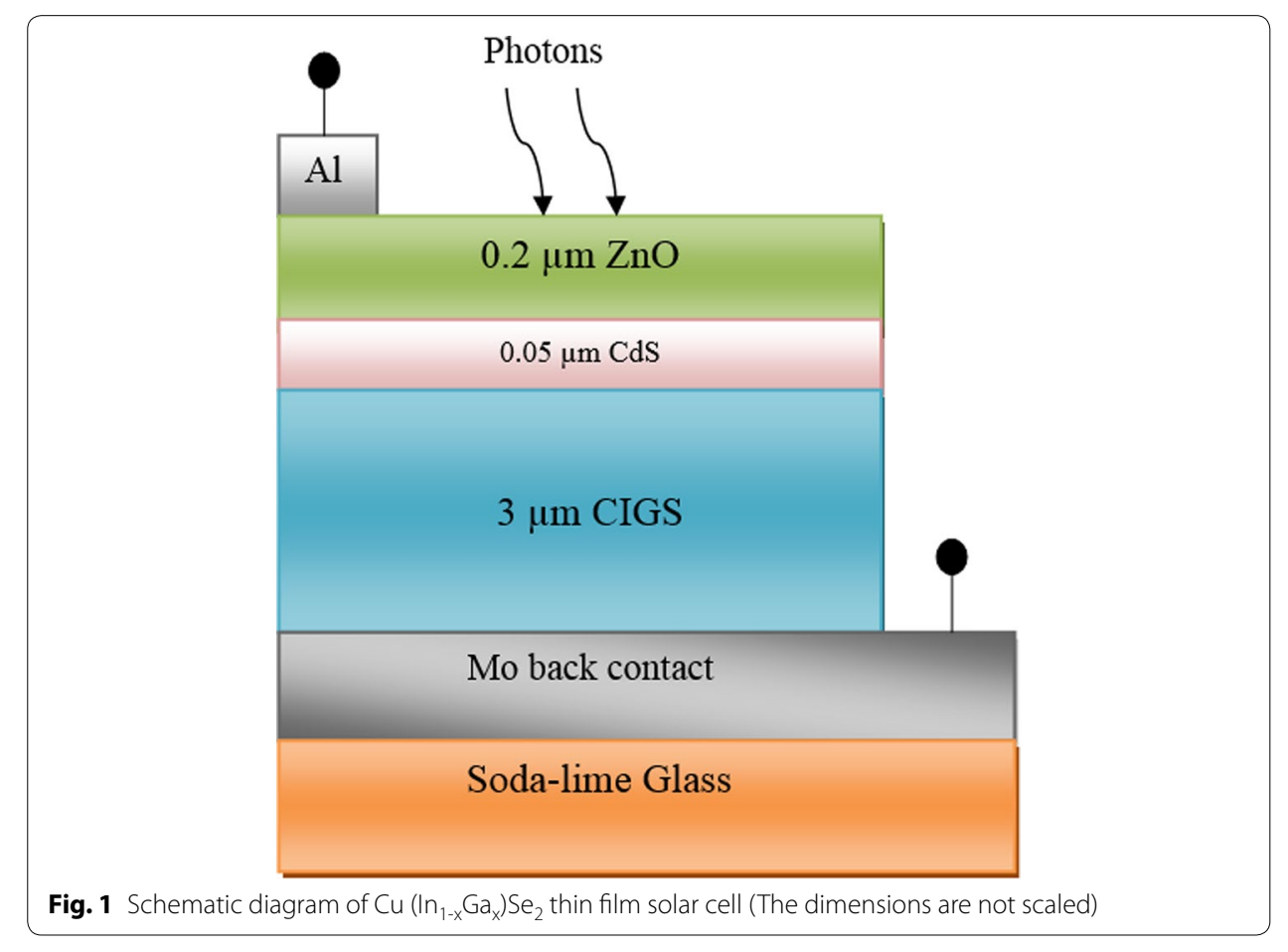


Table 1 The default values of device parameters

\begin{tabular}{llll}
\hline Parameters & N-ZnO & N-CdS & P-CIGS \\
\hline Thickness ( $\mu \mathrm{m})$ & 0.2 & 0.05 & 3 \\
Dielectric constant & 7.8 & 8.28 & 13.6 \\
Refractive index & 2 & 3.16 & 3.67 \\
Band gap (eV) & 3.3 & 2.42 & 1.15 \\
Electron affinity (eV) & 4.6 & 4.4 & 4.5 \\
Electron mobility (cm $\left.{ }^{2} \mathrm{Ns}\right)$ & 160 & 350 & 100 \\
Hole mobility (cm $\left.{ }^{2} \mathrm{Ns}\right)$ & 40 & 50 & 25 \\
Conduction band effective density of states $\left(\mathrm{cm}^{-3}\right)$ & $2.2 \times 10^{18}$ & $1.7 \times 10^{19}$ & $2 \times 10^{18}$ \\
Valence band effective density of states $\left(\mathrm{cm}^{-3}\right)$ & $1.8 \times 10^{19}$ & $2.4 \times 10^{18}$ & $1.6 \times 10^{19}$ \\
Donor concentration $\left(\mathrm{cm}^{-3}\right)$ & $1 \times 10^{18}$ & $1 \times 10^{18}$ & 0 \\
Acceptor concentration $\left(\mathrm{cm}^{-3}\right)$ & 0 & 0 & $2 \times 10^{16}$ \\
Electron lifetime $(\mathrm{s})$ & $5 \times 10^{-8}$ & $2 \times 10^{-8}$ & $1 \times 10^{-8}$ \\
Hole lifetime $(\mathrm{s})$ & $5 \times 10^{-9}$ & $6 \times 10^{-8}$ & $5 \times 10^{-8}$ \\
Absorption file & $\mathrm{zno.a}$ & $\mathrm{cds} . \mathrm{a}$ & $\mathrm{cigs.a}$ \\
\hline
\end{tabular}

Table 2 Contact parameters for device simulation

\begin{tabular}{lll}
\hline Parameters & Front contact & Back contact \\
\hline Reflectance & 0.1 & 0.8 \\
Recombination velocity for holes & $10^{7}$ & $10^{7}$ \\
Recombination velocity for electrons & $10^{7}$ & $10^{7}$ \\
\hline
\end{tabular}

making variation of the thickness and doping concentration of each layer. The simulations have been conducted through varying only the particular parameter and by keeping other parameters as default. The material and electrical properties of each layer have been elicited from some reliable sources of numerical simulations and experimental works (Gloeckler et al. 2003; Chelvanathan et al. 2010; Bouloufa et al. 2007; Schlenker et al. 2007; Balboul et al. 2008; Hossain et al. 2011; Repins et al. 2009; Gloeckler et al. 2005; Jackson et al. 2007). As mentioned earlier, the band gap of CIGS layer along with its electron affinity is varied according to the change in " $x$ " content (Gorji et al. 2012). The absorption files used by the simulator define the absorption coefficient due to different wavelengths. These files and the values of the parameters corresponding to mid-gap defect states are extracted from (Gloeckler et al. 2003) for the constituent layers.

The values of energy band gap and electron affinity are varied due to the change in $\mathrm{Ga} /$ $(\mathrm{In}+\mathrm{Ga})$ ratios. The Table 3 shows the variation in band gap along with electron affinity

Table 3 Band gap and electron affinity of $\mathrm{Cu}\left(\mathrm{In}_{1-\mathrm{x}} \mathrm{Ga}_{\mathrm{x}}\right) \mathrm{Se}_{2}$ alloy composition

\begin{tabular}{lll}
\hline $\mathbf{G a} /(\mathbf{I n}+\mathbf{G a})$ ratio, $\mathbf{x}$ & Band gap, $\mathbf{E}_{\mathbf{g}}$ & Electron affinity, $\mathbf{X}_{\mathbf{e}}$ \\
\hline 0.0 & 1.04 & 4.61 \\
0.3 & 1.20 & 4.25 \\
0.7 & 1.40 & 3.93 \\
1.0 & 1.67 & 3.41 \\
\hline
\end{tabular}


of $\mathrm{Cu}\left(\mathrm{In}_{1-\mathrm{x}} \mathrm{Ga}_{\mathrm{x}}\right) \mathrm{Se}_{2}$ layer with respect to the variation in "x" (Song et al. 2004; Klein et al. 1996; Dejene 2009; Johnson 2004; Li et al. 2009; Minemoto et al. 2001; Gloeckler and Sites 2005; Černivec et al. 2007) which can successively be plotted through curve fitting as shown in Fig. 2.

The mathematical Eqs. (1) and (2) were derived through fitting the curve by using the values put in Table 3.

$$
\begin{aligned}
& E_{g}=1.04+0.391 x+0.262 x^{2} \\
& \chi_{e}=4.61-1.162 x+0.034 x^{2}
\end{aligned}
$$

It can be remarked that the band gap increases and the electron affinity decreases with the raising of " $x$ ". Initially, the effect of absorber layer band gap was observed to determine the optimum result. Then, the energy band profile with optimum band gap and the efficiency graph due to the variation in energy gap were plotted. Afterwards, the doping concentration of each layer was varied and the optimal level of doping was determined by analyzing the corresponding efficiencies. Finally, the efficiency was calculated by using the optimized values and hence the highest performance was obtained.

\section{Results and discussion}

\section{Simulation outcome with default values}

The simulation was conducted successively with the default data used in Tables 1 and 2 which results in the light J-V characteristics curve. The open circuit voltage was obtained as $0.639 \mathrm{~V}$, while the short circuit current was $36.41 \mathrm{~mA} / \mathrm{cm}^{2}$. Then the fill factor (FF) and the efficiency were calculated as 78.38 and $18.23 \%$ respectively. Figure 3 shows the $\mathrm{J}-\mathrm{V}$ characteristic curve.

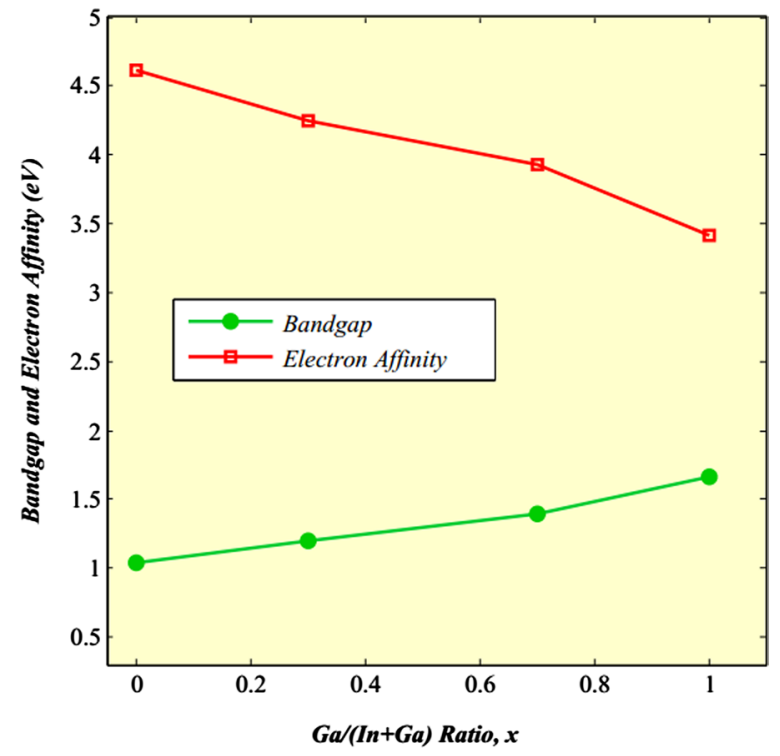

Fig. 2 Variation in band gap and electron affinity due to the change in Ga content 


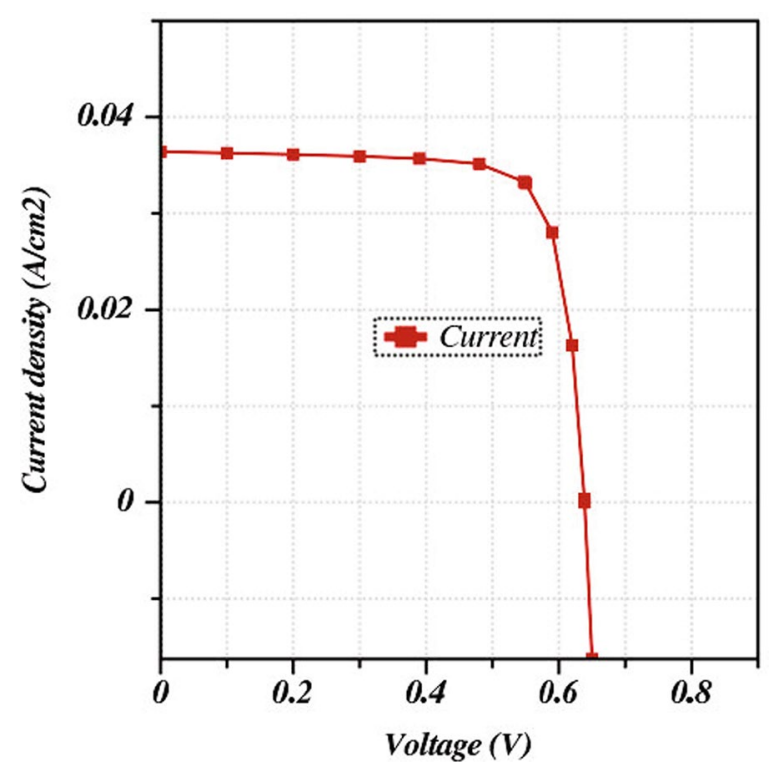

Fig. 3 J-V characteristic curve for default values

\section{Effect of absorber layer band gap on cell efficiency}

The $\mathrm{Cu}\left(\mathrm{In}_{1-\mathrm{x}} \mathrm{Ga}_{\mathrm{x}}\right) \mathrm{Se}_{2}$ layer energy band gap was varied from 1.04 to $1.69 \mathrm{eV}$ and keeping the other parameters as default the corresponding efficiencies were calculated. However, the efficiency increases with the wider band gap and after certain level the efficiency decreases in spite of increasing the band gap. Furthermore, the lattice mismatch effect is an important issue to be noted in this case. The CIGS cell suffers from lattice mismatch effect for the $\mathrm{Ga} /(\mathrm{In}+\mathrm{Ga}$ ) ratio above 0.35 (Song and Campbell 2013). The Table 4 shows the variation in band gap, electron affinity, and cell performance due to the change in $\mathrm{Ga}$ fraction. In a good agreement with simulation result, the optimal band gap of the CIGS absorber was chosen as $1.21 \mathrm{eV}$ while the electron affinity was calculated as $4.21 \mathrm{eV}$. Because the band gap greater than $1.21 \mathrm{eV}$ causes reducing the absorption within the layer and hence decreasing the short-circuit current. On the other side, the open circuit voltage increases linearly with the band gap variation.

Determining the absorber band gap as $1.21 \mathrm{eV}$ the energy band diagram for the entire solar cell structure was obtained as shown in Fig. 4.

Table 4 Performance variation due to absorber band gap

\begin{tabular}{lllllll}
\hline $\mathbf{X}$ & $\mathbf{E}_{\mathbf{g}}(\mathbf{e V})$ & $\mathbf{X}_{\mathbf{e}}(\mathbf{e V})$ & $\mathbf{J}_{\mathbf{s c}}\left(\mathbf{m A} / \mathbf{c m}^{\mathbf{2}}\right)$ & $\mathbf{V}_{\mathbf{o c}}(\mathbf{V})$ & $\mathbf{F F}(\%)$ & $\mathbf{n}(\%)$ \\
\hline 0 & 1.04 & 4.61 & 36.43 & 0.529 & 76.70 & 14.79 \\
0.2 & 1.13 & 4.38 & 36.22 & 0.622 & 77.68 & 17.49 \\
0.35 & 1.21 & 4.21 & 36.06 & 0.705 & 76.44 & 19.45 \\
0.55 & 1.33 & 3.98 & 35.84 & 0.828 & 66.60 & 19.77 \\
0.7 & 1.44 & 3.81 & 35.69 & 0.940 & 55.90 & 18.43 \\
1 & 1.69 & 3.48 & 35.45 & 1.183 & 32.16 & 13.49 \\
\hline
\end{tabular}




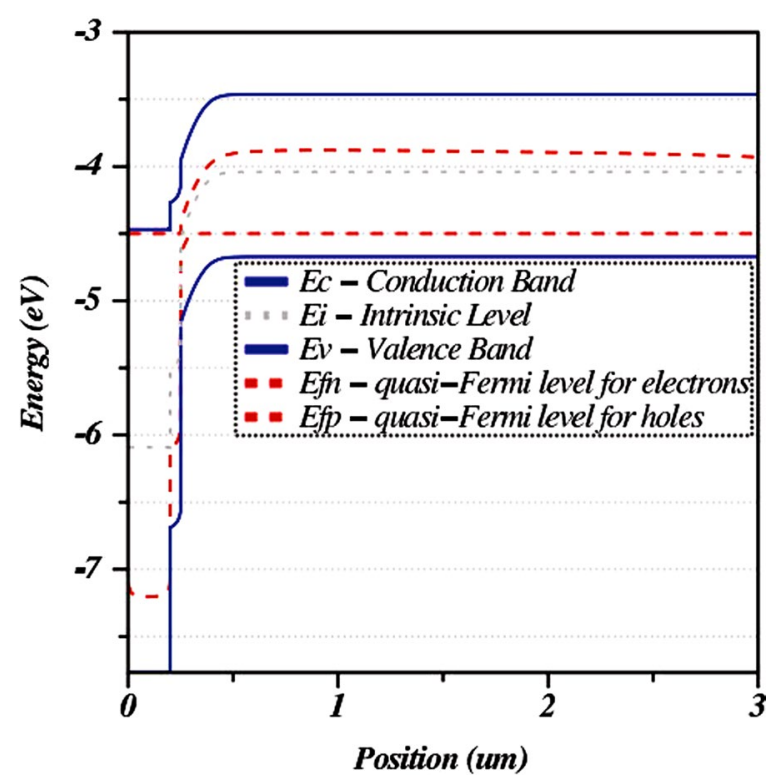

Fig. 4 Energy band diagram of CIGS thin film

\section{Effect of doping concentration on cell efficiency}

The $\mathrm{ZnO}$ window layer doping concentration was varied from $1 \times 10^{17}$ to $1 \times 10^{19} \mathrm{~cm}^{-3}$ and the corresponding efficiencies were calculated to obtain the optimal doping level by comparing the outcomes. Hence, the optimal doping density was dictated as $1 \times 10^{18} \mathrm{~cm}^{-3}$.

The doping density of CdS buffer on n-p junction (constituted between the buffer and the absorber) highly affects the output current. Analyzing the effects of drift velocity and holes recombination rate (Lee et al. 2009), the optimum doping concentration of CdS buffer layer was obtained as $5 \times 10^{18} \mathrm{~cm}^{-3}$.

The determined higher doping level of the absorber, $1 \times 10^{19} \mathrm{~cm}^{-3}$, is satisfactory for the electron affinity of the CIGS absorber, $4.21 \mathrm{eV}$.

\section{Optimized result}

As discussed earlier, the absorber layer optimal band gap of $1.21 \mathrm{eV}$ and the optimized doping concentration of all layers are determined through device simulation which in turn provides the highest performance. In Fig. 5a, describes the doping concentrations of different layers of designed CIGS solar cell, Fig. 5b shows the spatially resolved current, Fig. $5 \mathrm{c}$ denotes the electric field corresponding to the thickness of the layers and finally Fig. $5 \mathrm{~d}$ represents the J-V characteristic curve from which the optimum efficiency has been calculated. The simulation result presents the J-V characteristic curve with short-circuit current density of $33.09 \mathrm{~mA} / \mathrm{cm}^{2}$ and open circuit voltage of $0.856 \mathrm{~V}$. Finally, the maximum efficiency of CIGS thin film was calculated from the simulation outcomes as $24.27 \%$.

\section{Conclusions}

The numerical simulation of CIGS hetero-structure thin film solar cell was conducted by the ADEPT/F 2.1 one-dimensional online simulator. From various reliable sources the default values for simulation were collected and tabulated to obtain the default outcome. The mathematical equations of energy band gap and electron affinity for CIGS absorber as 

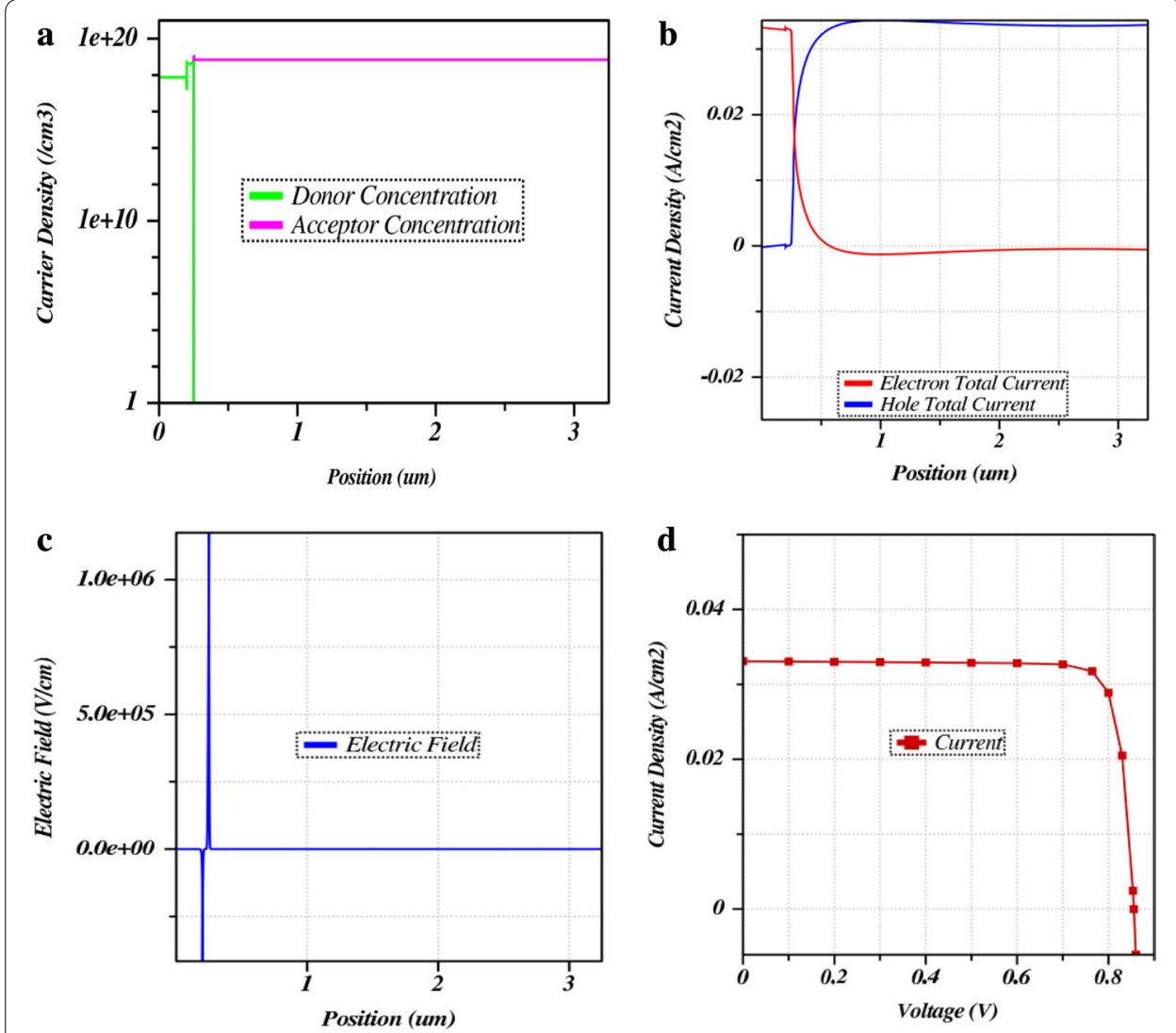

Fig. 5 a Doping concentration b Spatially resolved current c Electric field and $\mathbf{d} J-V$ characteristic curve for optimum values

a function of "x" were developed by plotting some known results. At different Ga fraction the absorber band gap and electron affinity were calculated. The simulation of the cell with the $\mathrm{Cu}\left(\mathrm{In}_{0.65} \mathrm{Ga}_{0.35}\right) \mathrm{Se}_{2}$ absorber layer results in higher efficiency rather than other compositions. Afterwards, the doping concentrations of the component layers were optimized in terms with drift velocity of the majority carrier and recombination rate of the minority carrier. At last, the cell performance was investigated by simulating with optimized values.

Authors' contributions

MA and MH conducted the design of study and led the simulation. ANB supervised the study and helped to draft the manuscript. All authors read and approved the final manuscript.

\section{Acknowledgements}

The authors would like to attribute their extreme gratitude to the researchers working in Purdue University, USA who contributed to develop the ADEPT/F simulator sponsored by Network for Photovoltaic Technology (NPT).

\section{Competing interests}

The authors declare that they have no competing interests.

Received: 16 December 2015 Accepted: 29 April 2016

Published online: 10 May 2016

\section{References}

Balboul MR, Schock HW, Fayak SA, El-Aal AA, Werner JH, Ramadan AA et al (2008) Correlation of structure parameters of absorber layer with efficiency of Cu(In, Ga)Se, solar cell. Appl Phys A 92(3):557-563. doi:10.1007/s00339-008-4630-Z Bouloufa A, Djessas K, Zegadi A (2007) Numerical simulation of Culn $\mathrm{Ga}_{1-x} \mathrm{Se}_{2}$ solar cells by AMPS-1D. Thin Solid Films 515(15):6285-6287. doi:10.1016/j.tsf.2006.12.110 
Černivec G, Burgelman M, Smole F, Topič M (2007) Investigation of the electronic properties of the recombination heterointerface in CGS/CIGS monolithic tandem solar cell. In: Proceedings of NUMOS (International Workshop on Numerical Modelling of Thin Film Solar Cells, Gent (B))

Chelvanathan P, Hossain MI, Amin N (2010) Performance analysis of copper-indium-gallium-diselenide (CIGS) solar cells with various buffer layers by SCAPS. Curr Appl Phys 10(3 Suppl.):S387-S391. doi:10.1016/j.cap.2010.02.018

Dejene FB (2009) The structural and material properties of CulnSe2 and Cu(In, Ga)Se2 prepared by selenization of stacks of metal and compound precursors by Se vapor for solar cell applications. Sol Energy Mater Sol Cells 93(5):577-582. doi:10.1016/j.solmat.2008.12.002

Gabor AM, Tuttle JR, Bode MH, Franz A, Tennant AL, Contreras MA et al (1996) Band-gap engineering in Cu(In, Ga) Se2 thin films grown from (In, Ga)2Se3 precursors. Sol Energy Mater Sol Cells 41-42:247-260

Gloeckler M, Sites JR (2005) Band-gap grading in Cu(In, Ga)Se2 solar cells. J Phys Chem Solids 66(11):1891-1894. doi:10.1016/j.jpcs.2005.09.087

Gloeckler M, Fahrenbruch AL, Sites JR (2003) Numerical modeling of CIGS and CdTe solar cells: setting the baseline. In: Proceedings of 3rd World Conference on photovoltaic energy conversion. Osaka

Gloeckler M, Sites JR, Metzger WK (2005) Grain-boundary recombination in Cu(In, Ga)Se2 solar cells. J Appl Phys 98(11):113704. doi:10.1063/1.2133906

Gorji NE, Perez MD, Reggiani U, Sandrolini L (2012) A new approach to valence and conduction band grading in CIGS thin film solar cells. Int J Eng Tec 4(5):573-576. doi:10.7763/ijet.2012.v4.435

Gray J, Wang X, Chavali RVK, Sun X, Kanti A, Wilcox JR et al (2015) ADEPT 2.1. https://nanohub.org/resources/adeptnpt. Accessed 12 Sept 2015

Haque KASME, Galib MMH (2013) An investigation into III-V compounds to reach 20\% efficiency with minimum cell Thickness in ultrathin-film solar cells. J Electron Mater 42(10):2867-2875. doi:10.1007/s11664-013-2693-x

Haque K, Quddus TNB, Ferdaous MT, Hoque MA (2013) An analysis of efficiency variation in an $\mathrm{Al}_{0.7} \mathrm{Ga}_{0.3} \mathrm{As} / \mathrm{Al}_{0.48} \mathrm{I}_{0.52} \mathrm{As}$ heterojunction solar cell with change in device parameters using adept 1D software. Electron Mater Lett 9(1):47-52. doi:10.1007/s13391-012-2087-x

Hossain MI, Chelvanathan P, Zaman M, Karim MR, Alghoul MA, Amin N et al (2011) Prospects of indium sulphide as an alternative to cadmium sulphide buffer layer in CIS based solar cells from numerical analysis. Chalcogenide Lett 8(5):315-324

Jackson P, Würz R, Rau U, Mattheis J, Kurth M, Schlötzer T et al (2007) High quality baseline for high efficiency, Cu(In1-X, Gax)Se2 solar cells. Prog Photovolt Res Appl 15(6):507-519. doi:10.1002/pip.757

Jackson P, Hariskos D, Wuerz R, Kiowski O, Bauer A, Friedlmeier TM (2015) Properties of Cu(In,Ga)Se2 solar cells with new record efficiencies up to 21.7\%. Phys Status Solidi-R 9(1):28-31. doi:10.1002/pssr.201409520

Johnson DC (2004) Novel capacitance measurements in copper indium gallium diselenide alloys. National Renewable Energy Laboratory. Available via NREL. http://www.nrel.gov/docs/fy04osti/35614.pdf. Accessed 12 Sept 2015

Jung S, Ahn S, Yun JH, Gwak J, Kim D, Yoon K et al (2010) Effects of Ga contents on properties of CIGS thin films and solar cells fabricated by co-evaporation technique. Curr Appl Phys 10(4):990-996. doi:10.1016/j.cap.2009.11.082

Klein A, Löher T, Pettenkofer C, Jaegermann W (1996) Chemical interaction of Na with cleaved (011) surfaces of CulnSe $2 . J$ Appl Phys 80(9):5039-5043. doi:10.1063/1.363549

Lee C, Efstathiadis H, Raynolds JE, Haldar P (2009) Two-dimensional computer modeling of single junction a-Si:H solar cells. In: 34th IEEE Photovoltaic Specialists Conference (PVSC), Philadelphia, PA, 7-12 June 2009, 001118-001122

Lee D-Y, Park S, Kim J (2011) Structural analysis of CIGS film prepared by chemical spray deposition. Curr Appl Phys 11(1 Suppl.):88-92. doi:10.1016/j.cap.2010.11.089

Li Z, Nishijima M, Yamada A, Konagai M (2009) Growth of Cu(In, Ga)Se2 thin films using ionization Ga source and application for solar cells. Phys Status Solidi (c) 6(5):1273-1277. doi:10.1002/pssc.200881180

Lindahl J, Zimmermann U, Szaniawski P, Torndahl T, Hultqvist A, Salome P et al (2013) Inline Cu(In, Ga)Se co-evaporation for high-efficiency solar cells and modules. IEEE J Photovolt 3(3):1100-1105. doi:10.1109/jphotov.2013.2256232

Minemoto T, Matsui T, Takakura H, Hamakawa Y, Negami T, Hashimoto Y et al (2001) Theoretical analysis of the effect of conduction band offset of window/CIS layers on performance of CIS solar cells using device simulation. Sol Energy Mater Sol Cells 67(1-4):83-88

Minemoto T, Hashimoto Y, Shams-Kolahi W, Satoh T, Negami T, Takakura H et al (2003) Control of conduction band offset in wide-gap Cu(In, Ga)Se2 solar cells. Sol Energy Mater Sol Cells 75(1-2):121-126

Powalla M, Dimmler B (2001) CIGS solar cells on the way to mass production: process statistics of a $30 \mathrm{~cm} \times 30 \mathrm{~cm}$ module line. Sol Energy Mater Sol Cells 67(1-4):337-344

Rampino S, Bronzoni M, Colace L, Frigeri P, Gombia E, Maragliano C et al (2015) Low temperature growth of single-crystal $\mathrm{Cu}(\mathrm{In}, \mathrm{Ga}) \mathrm{Se} 2$ films by pulsed electron deposition technique. Sol Energy Mater Sol Cells 133:82-86. doi:10.1016/j. solmat.2014.10.048

Repins I, Glynn S, Duenow J, Coutts TJ, Metzger WK, Contreras MA et al (2009) Required material properties for highefficiency CIGS modules. In: SPIE solar energy + technology, International Society for Optics and Photonics 7409:74090 M-74090 M-14

Schlenker E, Mertens V, Parisi J, Reineke-Koch R, Köntges M et al (2007) Schottky contact analysis of photovoltaic chalcopyrite thin film absorbers. Phys Lett A 362(2-3):229-233. doi:10.1016/j.physleta.2006.10.039

Song SH, Campbell SA (2013) Heteroepitaxy and the performance of CIGS solar cells. In: 39th IEEE Photovoltaic Specialists Conference (PVSC), Tampa, FL, 16-21, 2534-2539

Song J, Li SS, Huang CH, Crisalle OD, Anderson TJ (2004) Device modeling and simulation of the performance of Cu( $\mathrm{In}_{1-x^{\prime}}$ Gax)Se2 solar cells. Solid State Electron 48(1):73-79. doi:10.1016/S0038-1101(03)00289-2

Tverjanovich A, Borisov EN, Vasilieva ES, Tolochko OV, Vahhi IE, Bereznev S et al (2006) CulnSe 2 thin films deposited by UV laser ablation. Sol Energy Mater Sol Cells 90(20):3624-3632. doi:10.1016/j.solmat.2006.06.057 